SмIтн, H. G. (1959). J. gen. Microbiol. 21, 61-71

\title{
On the Nature of the Selective Action of Selenite Broth
}

\author{
By H. G. SMITH \\ Public Health Laboratory, Bradford
}

\begin{abstract}
SUMMARY : Sodium selenite is toxic in low concentration to salmonellas as well as to other enterobacteria. The ability of salmonellas to grow in selenite broth appears to be due to binding of selenite by constituents of peptone(e.g.peptides). Reduction of selenite takes place after growth is established and the intensity of reduction is related to the profuseness of growth. The presence of a fermentable carbohydrate favours growth and intensity of selenite reduction. Many organisms, however, die as a result of the reducing conditions. Organisms differ in their ability to use different sulphur sources; there was evidence that cystine and pentathionate as highly preferred sulphur sources may be of special significance. Sodium selenite reacts with certain inorganic sulphur compounds to form seleno-polythionates. It is believed that the selectivity of selenite broth may be due to the presence of seleno-polythionates or other seleno-sulphur compounds which act as growth-inhibitory analogues of highly preferred sulphur sources.
\end{abstract}

That bacteria are capable of reducing selenium salts to selenium has been known for over a century and has been the subject of a number of investigations. A review of the literature was made by Levine (1925), who studied the effects of various selenium compounds upon growth and upon the reducing powers of a number of bacteria, and found that the compounds could be arranged in a series of diminishing toxicity, e.g. selenium dioxide (selenious acid), selenic acid, sodium selenite, sodium selenate, potassium selenocyanide. In cultures containing selenite or selenate there was formation of brick-red selenium which was partly precipitated and partly colloidal. Reduction took place only when growth occurred and the degree of reduction paralleled growth, an observation also made by Klett (1900). With diphtheria bacilli, Levine found granules of selenium deposited within the cells and regarded reduction as an intracellular phenomenon.

Leifson (1936) produced an enrichment medium containing sodium selenite $\left(\mathrm{NaHSeO}_{3}\right)$ which is now widely used for the routine isolation of salmonellas. Little is known about the reasons for the selectivity of this medium. Selenite broth is a relatively simple medium and, as stressed by Leifson, contains no chemicals of unknown composition except the peptone. It appeared to be a suitable medium for the present study, which is concerned with an attempt to elucidate the basis of selectivity of selenite broth. Because of the emphasis laid on the reduction of selenium compounds by bacteria it seemed important to study the growth of different enterobacteria in selenite broth and the significance of the reduction of the selenite in relation to the selectivity of the medium. It was felt that little headway would be made without more knowledge of the nutrition of the organisms used. From this aspect a number of strains of Salmonella choleraesuis have been included among the organisms 
studied since this serotype is inhibited in selenite broth (Williams Smith, 1952) and any differences between it and $S$. typhimurium which might be revealed might help to elucidate the nature of the selective action of selenite broth.

\section{METHODS}

Media. The formulae for the different culture media used are shown in Table 1. For peptone, Difco Proteose-Peptone was used throughout. The media were as follows.

Selenite broth. This was prepared according to Hobbs \& Allison's modification (1945) of Leifson's formula (1936), in which mannitol is substituted for lactose. The medium was sterilized by steaming for $\mathbf{3 0} \mathrm{min}$.

Table 1. Composition of media used

\begin{tabular}{|c|c|c|c|c|c|}
\hline & $\begin{array}{c}\text { Selenite } \\
\text { broth }\end{array}$ & $\begin{array}{l}\text { Mannitol } \\
\text { peptone } \\
\text { medium }\end{array}$ & $\begin{array}{l}\text { Depleted } \\
\text { medium }\end{array}$ & $\begin{array}{l}\text { Defined } \\
\text { medium }\end{array}$ & $\begin{array}{l}\text { Defined } \\
\text { 'sulphur- } \\
\text { free' } \\
\text { medium }\end{array}$ \\
\hline Peptone (g.) & $\mathbf{5}$ & 5 & 5 & - & - \\
\hline $\mathrm{Na}_{2} \mathrm{HPO}_{4}$ (g.) & 10 & 10 & 10 & - & - \\
\hline$\left(\mathrm{NH}_{4}\right)_{2} \mathrm{HPO}_{4} 2 \mathrm{H}_{2} \mathrm{O}$ (g.) & 一 & 一 & - & 4 & 4 \\
\hline $\mathrm{KH}_{2} \mathrm{PO}_{4}$ (g.) & - & - & - & $0 \cdot 4$ & $0 \cdot 4$ \\
\hline $\mathrm{MgSO}_{4} 7 \mathrm{H}_{2} \mathrm{O}$ (g.) & 一 & - & 一 & 0.5 & - \\
\hline $\mathrm{NaCl}$ (g.) & - & - & - & $\mathbf{1}$ & $\mathbf{1}$ \\
\hline $\mathrm{MgCL}_{2} 6 \mathrm{H}_{2} \mathrm{O}$ (g.) & - & 一 & - & - & 0.5 \\
\hline $\mathrm{NaHSeO}_{3}$ (g.) & 4 & 一 & - & - & - \\
\hline Carbohydrate (g.) & 4 & 4 & 4 & 5 & 5 \\
\hline Charcoal (g.) & - & - & 40 & - & - \\
\hline Distilled $\mathrm{H}_{2} \mathrm{O}$ (ml.) & 1000 & 1000 & 1000 & 1000 & 1000 \\
\hline pH & $7 \cdot 1$ & $7 \cdot 1$ & $7 \cdot 1$ & $7 \cdot 1$ & $7 \cdot 1$ \\
\hline
\end{tabular}

Mannitol peptone medium. This was prepared in the same way as selenite broth except that the sodium selenite was omitted and sterilization was carried out by autoclaving at $115^{\circ}$ for $10 \mathrm{~min}$.

Depleted medium. Mannitol peptone medium was adsorbed with $4 \%(w / v)$ charcoal (Farnol $12 \times \mathrm{S}$ carbon). This produced a biuret-negative medium which was sterilized by autoclaving at $115^{\circ}$ for $10 \mathrm{~min}$.

Chemically defined medium. The defined medium shown in Table 1 is a modification of the medium described by Gale (1947). For comparison with other media mannitol was used as carbon source. Sterilization was by autoclaving at $115^{\circ}$ for $10 \mathrm{~min}$. The concentration of thiamine (hydrochloride) used was $25 \mu \mathrm{g}$. $/ \mathrm{ml}$. and of L-cystine, L-cysteine and DL-methionine $20 \mu \mathrm{g} . / \mathrm{ml}$. Other amino acids were added to a final concentration of $100 \mu \mathrm{g} . / \mathrm{ml}$. Inorganic sulphur compounds used as supplements were added to a final concentration of $0.1 \%(w / v)$.

'Sulphur-free' defined medium was also used for a small number of experiments.

Organisms. A number of strains of Salmonella choleraesuis was obtained from the National Collection of Type Cultures; other organisms were isolated 
from routine laboratory specimens. They included: serotypes of salmonellas, Escherichia coli I, Citrobacter freundii I, Klebsiella aerogenes I and Proteus vulgaris.

\section{RESULTS}

\section{Growth of organisms of Enterobacteriaceae in selenite broth}

Different types of organisms were selected for special study of their growth in selenite broth; colony counts were made by the method of Miles \& Misra (1938). An average of two samples was taken for estimation of viable counts. Figure 1 shows the growth of Salmonella typhimurium, Citrobacter freundii I, Proteus vulgaris, Escherichia coli I and Klebsiella aerogenes I, from which it may be seen that growth of $E$. coli I and $K$. aerogenes I was suppressed in com-

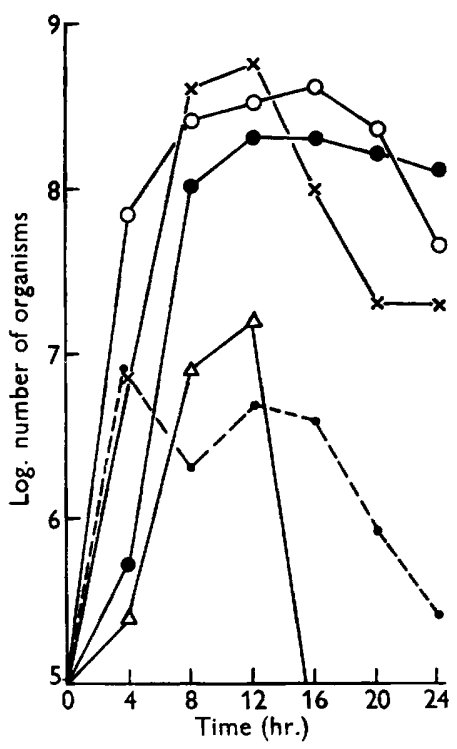

Fig. 1

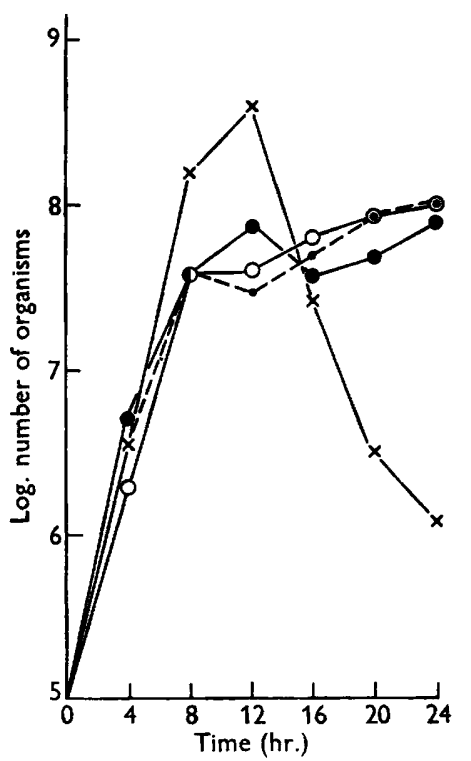

Fig. 2

Fig. 1. Growth of organisms in selenite broth. Inoculum 0.02 $\mathrm{ml} . \times 10^{-1}$ of an overnight broth culture. $-\times-$, Salmonella typhimurium; - -- , Citrobacter freundii I; - , Proteus vulgaris ; $-\triangle-$, Escherichia coli $\mathrm{I} ;---$, Klebsiella aerogenes $\mathrm{I}$.

Fig. 2. Growth of Salmonella typhi in selenite broth containing different carbohydrates. Inoculum $0.02 \mathrm{ml} \times 10^{-1}$ of an overnight broth culture. $-0-$, Lactose ; $-\times-$, mannitol; - - , sucrose; -- , no carbohydrate.

parison with the other organisms. There was no evidence of reduction of selenite to selenium until after $8 \mathrm{hr}$. of incubation, when the selenite at first became yellowish and gradually changed to a brick-red colour. Reduction of selenite to selenium followed bacterial growth therefore, and took place when maximal growth was reached. At the same time that macroscopic reduction was observed selenium granules were also seen microscopically inside the organisms or adhering to their surfaces, with numerous selenium granules free in the medium. 
It was evident that the selective action of selenite broth was not dependent on reduction of sodium selenite and that it occurred early in the growth period, before reduction of selenite took place. Reduction of the selenium compound to selenium was extracellular and intracellular, and the intensity of reduction was proportional to the luxuriance of growth of the organisms. Growth was greatly enhanced, however, by the presence of a fermentable carbohydrate. This is illustrated by the growth of Salmonella typhi shown in Fig. 2. The more rapid decrease in colony count in mannitol selenite broth was accompanied by a much greater intensity of reduction of the selenium compound than in selenite broth without added fermentable carbohydrate.

\section{The protective action of peptone on the toxicity of selenite}

When peptone medium was treated with charcoal (Farnol $12 \times \mathrm{S}$ carbon) peptides were adsorbed and the medium became biuret-negative but still supported the growth of Salmonella typhimurium. Selenite broth treated in the same way with charcoal inhibited the growth of $\boldsymbol{S}$. typhimurium. The inhibitory effect of charcoal on selenite broth emphasizes the importance of the peptone. In Table 2 the effect is shown of different concentrations of selenite

\section{Table 2. Growth of organisms in mannitol peptone medium with different} concentrations of selenite

Inoculum $0.02 \mathrm{ml} . \times 10^{-2}$ of an overnight broth culture to $10 \mathrm{ml}$. of the medium. Incubated at $37^{\circ}$ for $24 \mathrm{hr}$. Heavy growth, ++++ ; good growth, +++ ; moderate growth, ++ ; slight growth, + ; very slight growth, \pm ; no growth, - .

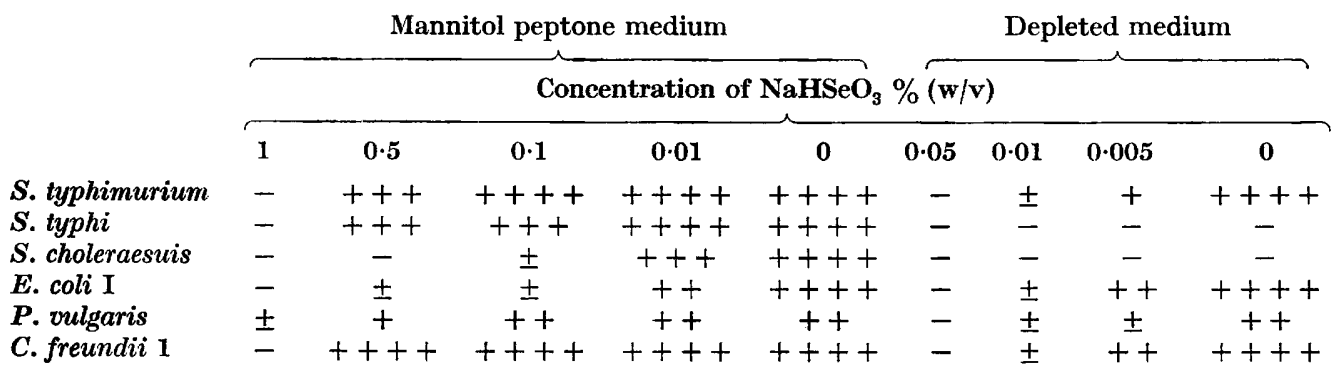

in mannitol peptone medium. Though a concentration of $1 \%(\mathrm{w} / \mathrm{v})$ sodium selenite suppressed the growth of almost all the organisms tested, $0.5 \%(\mathrm{w} / \mathrm{v})$ allowed a good growth of some and was, therefore, a selective concentration. Comparison with different concentrations of selenite in depleted medium (Table 2) shows that in the biuret-negative medium selenite was toxic in low concentration to all the organisms tested. In depleted medium without selenite there was no growth of $S$. typhi or the laboratory strain of $S$. choleraesuis within $24 \mathrm{hr}$. Thus, the evidence from these experiments suggests that substances present in peptone, absorbable by the charcoal used, were necessary not only to protect organisms from the toxic effects of selenite but also to confer a degree of selectivity on the medium. 


\section{Comparison of enterobacteria in different media}

The importance of protein derivatives such as peptides in relation to toxicity provides some grounds for suspecting that the basis of selectivity of selenite broth is largely nutritional. The growth characteristics, therefore, of a number of organisms were compared in selenite broth, mannitol peptone medium, depleted medium and defined medium. In Table 3 it may be seen that the growth of Escherichia coli I, though suppressed in selenite broth, was luxuriant in the three non-selective media. On the other hand, Citrobacter freundii $I$ was able to grow well in all the media except defined medium; in defined medium its growth was largely dependent on the size of the inoculum. Growth of all the strains of Salmonella choleraesuis was inhibited in selenite broth; three strains did not grow in depleted medium but produced a good growth in $24 \mathrm{hr}$. when thiamine was added; defined medium, even with the addition of thiamine, was inadequate for growth of all strains.

Table 3. Growth of organisms in different media

Inoculum $0.02 \mathrm{ml} . \times 10^{-3}$ of an overnight broth culture. Incubated at $37^{\circ}$ for $24 \mathrm{hr}$. Arbitrary assessment of growth as before.

$\begin{array}{lcccc} & \begin{array}{c}\text { Selenite } \\ \text { broth }\end{array} & \begin{array}{c}\text { Mannitol } \\ \text { peptone } \\ \text { medium }\end{array} & \begin{array}{c}\text { Depleted } \\ \text { medium }\end{array} & \begin{array}{c}\text { Defined } \\ \text { medium }\end{array} \\ \begin{array}{l}\text { S. } \text { typhimurium } \\ \text { E. coli I }\end{array} & +++ & ++++ & ++++ & ++++ \\ \begin{array}{l}\text { C. freundii I } \\ \text { S. choleraesuis } \text { strains }\end{array} & +++ & ++++ & ++++ & ++++ \\ \text { Lab. strain } & - & ++++ & ++++ & - \\ \text { NCTC 5364 } & - & ++++ & - & - \\ \text { NCTC 5735 } & - & ++++ & - & - \\ \text { NCTC 6678 } & - & ++++ & - & - \\ \text { NCTC 5736 } & - & ++++ & ++ & - \\ \text { NCTC 5737 } & - & ++++ & ++ & - \\ \text { NCTC 5738 } & - & ++++ & ++ & - \\ & & ++++ & ++ & -\end{array}$

\section{Hydrogen sulphide production and selenite reduction}

Observations of growth in selenite broth showed that intense reduction of selenite to selenium did not take place until the peak of the logarithmic phase had been reached. This was roughly similar in time to the production of $\mathrm{H}_{2} \mathrm{~S}$ as indicated by blackening of lead acetate paper strips. $\mathrm{H}_{2} \mathrm{~S}$ is known to react with selenious acid according to the equation

$$
\mathrm{H}_{2} \mathrm{SeO}_{3}+2 \mathrm{H}_{2} \mathrm{~S}=2 \mathrm{~S}+\mathrm{Se}+3 \mathrm{H}_{2} \mathrm{O} \text {. }
$$

When $\mathrm{Na}_{2} \mathrm{~S}$ is added to $\mathrm{NaHSeO}_{3}$ in solution, sulphur is first precipitated, followed by precipitation of selenium. $\mathrm{H}_{2} \mathrm{~S}$ production cannot be detected with lead acetate paper when using selenite broth; this is understandable in view of the reaction with selenite. The activity of organisms in producing $\mathrm{H}_{2} \mathrm{~S}$ is therefore of some importance in the reduction of selenite. This was studied in mannitol peptone medium and in depleted medium + cystine, since no $\mathrm{H}_{2} \mathrm{~S}$ was produced in depleted medium alone by any of the organisms tested. The 
results are shown in Table 4. It is noteworthy that the organisms which grew well in selenite broth were active $\mathrm{H}_{2} \mathrm{~S}$ producers in mannitol peptone medium and in depleted medium + cystine. Escherichia coli I did not produce $\mathrm{H}_{2} \mathrm{~S}$ in mannitol peptone medium but produced $\mathrm{H}_{2} \mathrm{~S}$ strongly from depleted medium + cystine. It would appear, then, that free cystine (or cysteine) was not present in mannitol peptone medium at the physiological stage of selenite reduction. Excess cystine must, therefore, exist as a component of complex substances (e.g. peptides) and the inability of $E$. coli $\mathrm{I}$ to produce $\mathrm{H}_{2} \mathrm{~S}$ in mannitol peptone medium may be due, perhaps, to the lack of enzymes necessary to free cystine in a suitable form for reduction.

\section{Table 4. $\mathrm{H}_{2} \mathrm{~S}$ production in mannitol peptone medium and depleted medium with cystine}

Thiamine was added to depleted medium for Salmonella choleraesuis strains. Complete blackening of surface of lead acetate paper represented by symbol ++++ ; slight marginal blackening \pm ; intermediate degrees,+++ , and +++ ; variable ( ). Incubated for $24 \mathrm{hr}$. at $37^{\circ}$.

$\begin{array}{ccccc} & \text { S. typhimurium } & \text { E. coli I } & \text { C. freundii I } & \text { P. vulgaris } \\ \begin{array}{l}\text { Mannitol peptone } \\ \text { medium }\end{array} & +++ & - & +++ & ++++ \\ \text { Depleted medium } & ++++ & ++++ & ++++ & ++++\end{array}$

S. choleraesuis strains

$\begin{array}{lccccccc} & \text { Lab. } & \text { NCTC } & \text { NCTC } & \text { NCTC } & \text { NCTC } & \text { NCTC } & \text { NCTC } \\ & \text { strain } & \mathbf{5 3 6 4} & \mathbf{5 7 3 5} & \mathbf{6 6 7 8} & \mathbf{5 7 3 6} & \mathbf{5 7 3 7} & \mathbf{5 7 3 8} \\ \begin{array}{l}\text { Mannitol peptone } \\ \text { medium }\end{array} & - & - & - & +++ & +++ & +++ & ++ \\ \begin{array}{l}\text { Depleted medium } \\ + \text { cystine }\end{array} & - & (+) & (+) & (+) & ++ & ( \pm) & ( \pm)\end{array}$

When cystine was added to selenite broth there was a greater intensity of reduction of selenite with Salmonella typhimurium and with Escherichia coli $\mathbf{I}$. Also, with $E$. coli I growth was greatly enhanced before selenite reduction took place. Strains of $S$. choleraesuis which required thiamine did not produce $\mathrm{H}_{2} \mathrm{~S}$ in mannitol peptone medium while the remaining strains were moderately active $\mathrm{H}_{2} \mathrm{~S}$ producers. All the strains of $S$. choleraesuis had little or no activity in depleted medium + cystine.

\section{The relationship of sulphur metabolism to growth in selenite broth}

The effect of adding different sulphur sources on the growth of organisms was studied. The more important findings have been collected in Table 5 . It may be seen that in depleted medium + selenite, cystine was able to annul the toxic effect of the selenite on the growth of Salmonella typhimurium and Escherichia coli I, while methionine had no effect. Further information on the relationship of cystine and methionine to selenite was obtained with Citrobacter freundii I. No growth of $C$. freundii I was obtained in defined medium. The addition of methionine to the medium allowed a poor growth in $24 \mathrm{hr}$., but maximal growth was obtained when glutamic acid and glycine were also added. 
No growth was obtained with cystine in $24 \mathrm{hr}$. In defined 'sulphur-free' medium the growth was poor when methionine was the sole sulphur source but maximal with cystine + methionine. Thus methionine with either sulphate or cystine would seem to be essential for optimal growth. With $C$. freundii $I$ in defined medium + selenite growth occurred only with cystine + methionine. It is clear that even when methionine was required for optimal growth, cystine was necessary to overcome the toxic effect of selenite.

Table 5. The effect of different sulphur sources on the growth of organisms in different media

For Citrobacter freundii I defined and defined 'sulphur-free' medium were fortified with glutamic acid and glycine and for Salmonella choleraesuis with glutamic acid, aspartic acid, and thiamine. The strains of $S$. choleraesuis are not designated but the results are tabulated in the order shown in Table 3. Time of incubation $24 \mathrm{hr}$. at $37^{\circ}$. Inoculum $0.02 \mathrm{ml} . \times 10^{-3}$ of an overnight broth culture to $10 \mathrm{ml}$. of the medium.

Growth is indicated by symbols as in Table 2.

\begin{tabular}{|c|c|c|c|c|c|c|}
\hline \multirow[b]{2}{*}{ Organisms } & \multirow[b]{2}{*}{ Medium } & \multicolumn{5}{|c|}{ Sulphur supplements } \\
\hline & & Nil & Cystine & Methionine & $\begin{array}{l}\text { Cystine + } \\
\text { methionine }\end{array}$ & $\mathrm{K}_{2} \mathrm{~S}_{5} \mathrm{O}_{6}$ \\
\hline $\begin{array}{l}\text { S. typhimurium } \\
\text { E. coli I }\end{array}$ & $\left\{\begin{array}{l}\text { Depleted medium }+ \\
0.5 \%(\mathrm{w} / \mathrm{v}) \mathrm{NaHSeO}_{3}\end{array}\right.$ & - & $\begin{array}{c}++++ \\
+++\end{array}$ & - & $\dot{.}$ & : \\
\hline C. freundii I & $\left\{\begin{array}{l}\text { Defined medium } \\
\text { Defined 'sulphur-free' } \\
\text { medium } \\
\text { Defined medium }+ \\
0 \cdot 1 \%(w / v) \mathrm{NaHSeO}_{3}\end{array}\right.$ & - & - & $\begin{array}{c}+++ \\
+\end{array}$ & $\begin{array}{l}++++ \\
++++ \\
++++\end{array}$ & $\dot{.}$ \\
\hline $\begin{array}{l}\text { S. choleraesuis } \\
\text { strains }\end{array}$ & $\left\{\begin{array}{l}\text { Selenite broth } \\
\text { S }\end{array}\right.$ & $\begin{array}{c}++ \\
\pm \\
+ \\
- \\
++ \\
++ \\
++ \\
- \\
- \\
= \\
- \\
- \\
-\end{array}$ & $\begin{array}{c}+++ \\
\pm \\
+++ \\
- \\
++ \\
+++ \\
- \\
- \\
++ \\
- \\
- \\
++ \\
++\end{array}$ & $\begin{array}{c}+++ \\
- \\
+++ \\
- \\
+++ \\
++++ \\
\pm \\
= \\
= \\
= \\
= \\
=\end{array}$ & $\begin{array}{c}+++ \\
+ \\
+++ \\
+ \\
++++ \\
++++ \\
+ \\
- \\
++++ \\
- \\
- \\
++ \\
++\end{array}$ & $\begin{array}{c}+++ \\
+ \\
+++ \\
- \\
+++ \\
++ \\
++ \\
+++ \\
- \\
+++ \\
+++ \\
+++ \\
+++ \\
+++\end{array}$ \\
\hline
\end{tabular}

The growth response of Salmonella choleraesuis strains to supplements of different sulphur sources was studied by using defined medium + glutamic acid + aspartic acid + thiamine. The quantity of pentathionate available was limited and was used almost entirely for studies with $S$. choleraesuis. Though the results (Table 5) were rather variable, nevertheless, cystine, methionine and pentathionate all made some contribution to enhancement of growth in defined medium. In selenite broth the most outstanding annulment of growth inhibition was obtained with pentathionate and not by cystine; methionine had no effect at all.

Growth studies with Escherichia coli I in selenite broth + different sulphur sources showed that pentathionate greatly enhanced growth, which was also 
improved by trithionate and dithionate, but to a much less extent. Investigation of growth of Salmonella typhimurium and $\boldsymbol{E}$. coli $I$ with very small inocula in defined medium and in defined 'sulphur-free' medium indicated that both organisms were able to utilize a wide range of sulphur sources and that growth was greatly enhanced by the addition of glutamic acid.

\section{The role of seleno-polythionates in selectivity}

Of the sulphur sources added to selenite broth sodium thiosulphate was of particular interest as it produced a strong precipitation of selenium and, provided its concentration was not too high, the medium allowed the growth of Salmonella typhimurium but completely suppressed the growth of Escherichia coli $\mathrm{I}$. When equal volumes of $10 \%(\mathrm{w} / \mathrm{v})$ sodium thiosulphate and $10 \%(\mathrm{w} / \mathrm{v})$ sodium selenite were mixed there was a heavy precipitation of selenium which deposited overnight to leave a water-clear fluid. The solution, whenever the selenium deposit was removed by filtration, repeatedly precipitated selenium so that the presence of elementary selenium seemed to impart a stability to the solution. The addition of more thiosulphate to the solution had no effect, but when selenite was added there was an immediate precipitation of selenium. Selenite cannot, therefore, co-exist with thiosulphate; nevertheless, the addition of $0.5 \mathrm{ml}$. of the $10 \%(\mathrm{w} / \mathrm{v})$ solution to $10 \mathrm{ml}$. mannitol peptone medium produced a medium with practically the same range of selectivity as selenite broth. Mellor (1930) gave an account of the reaction between thiosulphate and selenium dioxide from the work of Norris \& Fay (1900) and Heuer (1926). On the basis of these findings the reaction between sodium selenite and sodium thiosulphate is probably

$$
\text { (1) } \mathrm{NaHSeO}_{3}+4 \mathrm{Na}_{2} \mathrm{~S}_{2} \mathrm{O}_{3}+2 \mathrm{H}_{2} \mathrm{O}=\mathrm{Na}_{2} \mathrm{~S}_{4} \mathrm{O}_{6}+\mathrm{Na}_{2} \mathrm{SeS}_{4} \mathrm{O}_{6}+5 \mathrm{NaOH}
$$

followed by

$$
\text { (2) } 2 \mathrm{Na}_{2} \mathrm{SeS}_{4} \mathrm{O}_{6}+6 \mathrm{NaOH}=3 \mathrm{Na}_{2} \mathrm{~S}_{2} \mathrm{O}_{3}+2 \mathrm{Na}_{2} \mathrm{SO}_{3}+2 \mathrm{Se}+3 \mathrm{H}_{2} \mathrm{O} \text {. }
$$

From the chemical behaviour of the solution it would seem that rapid decomposition of sodium seleno-pentathionate occurs only in the absence of elementary selenium so that when a small amount of this compound has precipitated some selenium, reaction 2 is retarded.

The sodium tetrathionate found in reaction 1 probably decomposes rapidly and it is doubtful whether it contributes much, if anything, to the selective action of the mannitol peptone medium containing the thiosulphate + selenite solution. It is possible that other reactions given by Mellor (1930) may add to the complexity of the solution. For instance, tetrathionate may react with sulphite thus:

$$
\mathrm{Na}_{2} \mathrm{~S}_{4} \mathrm{O}_{6}+\mathrm{Na}_{2} \mathrm{SO}_{3}=\mathrm{Na}_{2} \mathrm{~S}_{3} \mathrm{O}_{6}+\mathrm{Na}_{2} \mathrm{~S}_{2} \mathrm{O}_{3}
$$

Trithionate may, however, combine with selenium to form sodium selenotetrathionate

$$
\mathrm{Na}_{2} \mathrm{~S}_{3} \mathrm{O}_{6}+\mathrm{Se}=\mathrm{Na}_{2} \mathrm{SeS}_{3} \mathrm{O}_{6}
$$


Seleno-pentathionate may also combine with sulphite to form sodium selenotrithionate which may then decompose as follows:

or

$$
\begin{aligned}
& \mathrm{Na}_{2} \mathrm{SeS}_{2} \mathrm{O}_{6}=\mathrm{Se}+\mathrm{SO}_{2}+\mathrm{Na}_{2} \mathrm{SO}_{4}, \\
& \mathrm{Na}_{2} \mathrm{SeS}_{2} \mathrm{O}_{6}=\mathrm{Na}_{2} \mathrm{~S}_{2} \mathrm{O}_{6}+\mathrm{Se} .
\end{aligned}
$$

It seems clear that the chemical interaction between sodium selenite and thiosulphate may result in an exceedingly complex solution of polythionates and seleno-polythionates as well as other sulphur compounds. Possibly selenopolythionates act as inhibitory analogues of highly preferred sulphur compounds and of these, seleno-pentathionate may be the most important since pentathionate has been shown to annul the inhibition of growth of Escherichia coli I and Salmonella choleraesuis in selenite broth.

\section{DISCUSSION}

Selenite broth is not, as might be supposed, a simple peptone medium in which free selenite is present. The experimental evidence indicates rather that some of the selenite is bound, perhaps by the peptides, while the remainder enters into chemical reactions with other substances present in the medium. The importance of the peptone used in the preparation of the medium is therefore clear, and it would be reasonable to assume that the quality of the selenite broth might be adversely affected by a variety of factors such as a diminution of selenite-binding properties or differences in cystine content.

Reduction of selenite is a late manifestation of the growth of the culture and is due to the activity of organisms which had already grown before the selenite was reduced. Selectivity due to selenite appears to be associated with sulphur metabolism. Though different sulphur sources were found to enhance the growth of Salmonella choleraesuis and Citrobacter freundii $\mathrm{I}$ in defined medium, studies of Escherichia coli I and $S$. typhimurium did not reveal significant differences in sulphur metabolism. Roberts, Abelson, Cowie, Bolton \& Britten (1955) found with $\boldsymbol{E}$. coli that a large group of sulphur compounds allowed optimal growth, but by using an isotopic competition method they were able to show differences in preference for different sulphur compounds. When either sulphate or sulphite were used as the sole sulphur source the growth responses were identical, though in mixtures of the two the organism preferred sulphite to sulphate. Thiosulphate was more effective than sulphite in suppressing the utilization of sulphate; cystine was found to be the most highly preferred of all the sulphur sources examined. Methionine allowed a suboptimal growth and it was necessary to supply some other sulphur source in addition to obtain optimal growth. With Torulopsis utilis sulphite was a more effective competitor than thiosulphate, cystine was a poor competitor with sulphate and methionine almost completely suppressed the incorporation of sulphate sulphur. Cystine and polythionates can be included among the sulphur sources that may be highly preferred by given bacteria and the effect of adding cystine or pentathionate to selenite broth, with organisms usually suppressed or inhibited by this medium, is almost certainly due to the provision of a highly preferred 
sulphur source. This implies that on a nutritional basis cystine and pentathionate can annul the inhibitory effects of substances (e.g. selenite) which block sulphate utilization.

The work of Roberts et al. (1955) suggests an important difference in sulphur metabolism between bacteria in which cystine is the most highly preferred sulphur source to permit optimal growth and yeasts in which methionine is the most highly preferred sulphur source. Cystine annuls the toxicity of selenate for Escherichia coli (Fels \& Cheldelin, 1949) and cysteine the toxicity of selenite (Opieńska-Blauth \& Iwanowski, 1952). North \& Bartram (1953) found that the addition of cystine to selenite broth enhanced the growth of Salmonella typhimurium. On the other hand, in yeast only methionine could annul the toxicity of selenate (Fels \& Cheldelin, 1948). Of the organisms studied in the present investigation those able to grow well in selenite broth seemed to have a high preference for cystine and this might be a dominant factor in selectivity, though $E$. coli I may be able to utilize only free cystine. Methionine, on the other hand, though necessary for optimal growth in Citrobacter freundii I, does not seem to be important in sulphur competition or to play any part in selectivity due to selenite.

The importance of polythionates (in particular pentathionate) in the sulphur competition field has been stressed. Pentathionate is likely to be highly preferred since it is able to annul the inhibitory effect of selenite broth on Escherichia coli I and Salmonella choleraesuis. Cystine, however, can annul the inhibitory effect of selenite broth on $E$. coli I but has very little effect with $S$. choleraesuis in the same medium. From this it is concluded that while $E$. coli I may have a higher preference for cystine over pentathionate, $S$. choleraesuis has a higher preference for pentathionate over cystine. The significance of these findings lies in the capacity of selenite to react with sulphur compounds to produce seleno-polythionates which are presumably toxic compounds. Seleno-pentathionate, found as a result of chemical reaction between selenite and thiosulphate, may, for instance, act as an inhibitory analogue of pentathionate. Possibly other seleno-sulphur compounds may be found in selenite broth. Though the reactions that may occur in selenite broth are not known, this would seem to be a rational explanation for the selective action of selenite broth inasmuch as it provides an explanation not only as to why some species of bacteria can overcome the toxic effects of the medium but also why the growth of some species is suppressed.

I wish to express my thanks to Mr Gordon Weston of the Department of Chemistry and Dyeing, Bradford Institute of Technology, for advice on the selenopolythionates and for kindly providing the polythionates used in this investigation. 


\section{REFERENCES}

Fels, I. G. \& Cheldelin, V. H. (1948). Methionine in selenium poisoning. J. biol. Chem. 176, 819.

Fels, I. G. \& Cheldelin, V. H. (1949). Selenate inhibition studies. III. The reversal of selenate inhibition in E. coli. Arch. Biochem. 22, 323.

GaLe, E. F. (1947). The Chemical Activities of Bacteria. London University Tutorial Press Ltd.

Heuer, O. (1926). Beitrag zur Kenntnis der Selenpolythionate, Nauen. (As cited in MELLOR, 1930.)

Hobss, B. C. \& Allison, V. D. (1945). Studies on the isolation of Bact. typhosum and Bact. paratyphosum B. III. Discussion, summary and conclusions. Mon. Bull. Minist. Hlth Lab. Serv. 4, 63.

Kuetr, A. (1900). Zur Kenntnis der reduzierenden Eigenschaften der Bacterien. Z. Hyg. InfektKr. 33, 137.

Lerfson, E. (1936). New selenite enrichment media for the isolation of typhoid and paratyphoid (Salmonella) bacilli. Amer. J. Hyg. 24, 423.

Levine, V. E. (1925). The reducing properties of micro-organisms with special reference to selenium compounds. J. Bact. 10, 217.

Melaor, J. W. (1930). Comprehensive Treatise on Inorganic and Theoretical Chemistry, x. London, New York and Toronto: Longmans, Green and Co.

MrLes, A. A. \& Misra, S. S. (1938). The estimation of the bactericidal power of the blood. J. Hyg., Camb. 38, 732.

Norris, J. F. \& FAY, H. (1900). The reduction of selenium dioxide by sodium thiosulphate. Amer. chem. J. 23, 119.

Nortir, W. R. \& Bartram, M. T. (1953). The efficiency of selenite broth of different compositions in the isolation of salmonella. Appl. Microbiol. 1, 130.

Opieńska-BlaUth, J. \& Iwanowski, H. (1952). The effect of selenite on the growth and glucose metabolism in the fluid cultures of E. coli. Acta microbiol. polon. 1, 273.

Roberts, R. B., Abelson, P. H., Cowie, D. B., Bolton, E. T. \& Britten, R. J. (1955). Studies of biosynthesis in Escherichia coli. Publ. Carneg. Instn, no. 607.

Wirliams Smith, H. (1952). The evaluation of culture media for the isolation of salmonellae from faeces. J. Hyg., Camb. 50, 21. 